\title{
nature
}

\section{A chance for change in France}

A budget crisis is crippling French science, despite the best efforts of the research minister. But the time is right for a radical and necessary reorganization of research.

$\mathrm{S}$ cience has been making headlines in France's newspapers, but not for the reasons that some might like. Laboratories are suffering from brutal and indiscriminate cuts by the centreright government, which has lopped as much as a third off some labs' budgets. Whatever the government's economic predicament, these cuts and the resulting job losses are sending the wrong signal to the young minds that French science badly needs to attract.

No wonder scientists are livid. Electoral pledges by President Jacques Chirac last year had left them expecting research to be a national priority, with annual spending being hiked from $2.2 \%$ of gross national product to $3 \%$ before 2010, in line with goals agreed by European Union heads of states (see page 6). Claudie Haigneré, the science minister, is sympathetic to the scientists' plight, and recently won a reprieve from a further round of cuts. But the best she can probably hope for is that a vague promise by Prime Minister Jean-Pierre Raffarin will lead to a better budget next year. What irks many is that the nation's scientific and technological fabric appears to be being sacrificed to pay for populist electoral promises such as tax cuts and a dubious spending spree on the police.

The critics have a point. The science-budget crisis is a symptom of an increasing political disengagement over recent decades. Now the ship is adrift without a captain. Substantial progress demands a renewed and sustained political commitment, and a new contract between science and government built on mutual confidence. Scientists themselves must shake up the bloated and bureaucratic French science system, so that it provides clearer goals, flexibility and cost-effectiveness, and responds to the aspirations of young scientists.

This will require strong and constructive contributions from all stakeholders, including the trade unions and a new and positively inclined generation of research leaders. Haigneré is contemplating a radical reform, transforming the country's large research organizations that run their own laboratories, so that they play a greater role as research councils, funding autonomous laboratories through competitive peer review. None of her predecessors succeeded in pulling this off, often because they tried to transpose and impose superficially appealing Anglo-Saxon models without taking into account the cultural realities of the French system.

Adopting what works well elsewhere would liberate French scientists from stifling centralization. Encouragingly, Haigneré seems to appreciate that change will require careful thought, as France's weak university system is in no fit state to manage the country's laboratories — progress may require a hybrid system involving the research organizations. She is in an unenviable position, but seems to have a sincere desire to listen, and to seek constructive ways forward; scientists and their trade unions should work with her, not against her.

But researchers can only do so much. Meeting the challenges of twenty-first-century science in France requires political leadership that is currently lacking. No French politician since has matched the powerful vision of the role of science and technology pioneered by Pierre Mendès France, who led a Socialist government in the early 1950s, and General Charles de Gaulle, who returned to power in 1958. Despite the competing demands of the need to build the socialsecurity system, and fighting wars in Indochina and Algeria, France's governments of the time turned that vision into an unprecedented expansion of science, taking France and Europe to the leading edge of molecular biology, space and nuclear technology. France, under Chirac, now has a similar opportunity - and for the sake of its and Europe's international status in science, France must take it.

\section{Rice institute needs strong support}

Despite rumours to the contrary, the role of the International Rice Research Institute is as important as ever.

$\mathrm{R}$ ice has been a great success story. Since the Green Revolution in the 1960s, rice production has more than doubled, thanks to a 2.5 -fold increase in productivity per hectare. Vietnam, which once struggled to meet its needs, is now an exporter. There is now more than enough rice to go around, but the eastern regions of India, suffering floods and soil alkalinity, struggle to meet their own needs despite the abundance of rice produced in the well-irrigated Punjab region. Telling people to redistribute rice won't help much. Local growers need to be able to look after themselves - for them, research into productivity continues to play an essential role.

The International Rice Research Institute (IRRI) near Manila in the Philippines is adapting to these circumstances. Rather than offering a finished product that can be used in any region, the institute is developing materials, methods and training so that breeders can take advantage of genomic tools to meet their local needs, whether the soil is acidic or alkaline, and whether the regions are prone to floods, drought or both (see Nature 422, 796-798; 2003).

The problems facing farmers will only get worse. Rice demand is expected to increase at $1 \%$ per year over the next 25 years. As sea levels rise and soil becomes salty and eroded, even greater productivity will be necessary. Nearly half of the diverted water in Asia goes to rice irrigation, but water, too, is becoming scarcer and tainted.

Researchers hope to tap the secrets of the rice genome to meet these challenges - a good bet, considering the unexplored biodiversity in the rice germ stocks. But there are significant obstacles to bringing genomic science to bear on farmers' practices. IRRI, whose rice lines have been bred into over a third of the new lines produced worldwide since the 1960 s, is well positioned to take up that challenge.

But the institute is facing huge cutbacks (see Nature 416,777;2002). In the three years from 2001 to 2003, IRRI's annual core funding dropped by $26 \%$, and similar cuts are expected in the future.

It is essential that support for IRRI be mobilized. Researchers there, where research that spurred the Green Revolution was carried out, sometimes hear their success in producing abundant, highyielding rice as a justification for cutting their budget, as if to say "your job is over". But the institute's job is not over - it has just begun. 